\title{
Fermented soyabean and vitamin C-rich fruit: a possibility to circumvent the further decrease of iron status among iron-deficient pregnant women in Indonesia
}

\author{
Maria Wijaya-Erhardt, Siti Muslimatun* and Juergen G Erhardt \\ Southeast Asian Ministers of Education Organization - Tropical Medicine Regional Center for Food and \\ Nutrition, University of Indonesia, J. Salemba Raya 6, Jakarta 10430, Indonesia
}

Submitted 24 July 2010: Accepted 24 March 2011: First published online 24 May 2011

\begin{abstract}
Objective: Increasing the consumption of Fe-rich foods and thus improving Fe bioavailability without significantly increasing diet cost is the most sustainable intervention for improving Fe intake. We assessed the effect of supplementary food consisting of fermented soyabean (tempeh) and vitamin C-rich fruit consumed during pregnancy on maternal iron deficiency (ID).

Design: Pregnant women were randomly allocated by village into optimized diet and control groups. Supplementary food was given $6 \mathrm{~d} /$ week at home. The average weekly food provided comprised $600 \mathrm{~g}$ of tempeh, $30 \mathrm{~g}$ of meat, $350 \mathrm{~g}$ of guava, $300 \mathrm{~g}$ of papaya and $100 \mathrm{~g}$ of orange. $\mathrm{Hb}$, ferritin and transferrin receptor (TfR) concentrations were measured at 12-20 and at 32-36 weeks of gestation. Setting: Thirty-nine villages in Indonesia.

Subjects: Pregnant women (12-20 weeks of gestation, $n$ 252).

Results: At baseline, mean $\mathrm{Hb}$, ferritin and $\mathrm{TfR}$ concentrations and body $\mathrm{Fe}$ concentration were within the normal range and did not differ between groups. At near term, mean $\mathrm{Hb}$, ferritin and body Fe decreased, whereas mean TfR increased significantly in both groups. The mean changes in Fe status were similar in both groups. In Fe-deficient women, consumption of an optimized diet was associated with smaller decreases in $\mathrm{Hb}(1.02(95 \% \mathrm{CI} 0 \cdot 98,1 \cdot 07) \mathrm{g} / \mathrm{l} ; P=0.058)$, ferritin $(1.42(95 \%$ CI $1 \cdot 16,1.75) \mu \mathrm{g} / 1 ; P=0.046)$ and body Fe $(2.57$ (95\% CI $1.71,3.43) \mathrm{mg} / \mathrm{kg} ; P=0.073)$ concentrations, compared with a state of no intervention. Fe-deficient women at baseline benefited more from supplementary food compared with Fe-replete women.

Conclusions: Daily supplementary food containing tempeh and vitamin C-rich fruits during pregnancy might have positive effects on maternal ID.
\end{abstract}

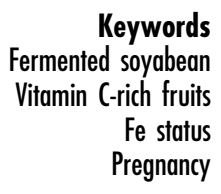

Iron-deficiency anaemia (IDA) among pregnant women is associated with an estimated 111000 maternal deaths each year ${ }^{(1)}$. Anaemia control programmes based on the administration of $\mathrm{Fe}$ and folic acid supplements have been implemented in many developing countries; however, the success is very limited and pregnant women are often deficient in a wider range of vitamins and minerals. Of the strategies to prevent iron deficiency (ID), foodbased approaches are considered the only sustainable and long-term solution that also provides nutrients other than $\mathrm{Fe}$ and adds variety to the diet ${ }^{(2)}$.

The following factors are important for alleviating ID: increasing Fe intake, especially of haem Fe; increasing the intake of absorption enhancers for non-haem Fe, such as vitamin $\mathrm{C}$ and meat proteins; decreasing the intake of inhibitors such as phytic acid (e.g. in beans) or tannins (e.g. in tea); and reducing Fe loss (e.g. caused by malaria, intestinal parasites). It is obvious that only an approach that addresses all these factors, which is adapted to local settings (especially with the use of locally available and familiar foods and preparation methods) ${ }^{(3)}$ and does not significantly increase the cost, is feasible in poor communities.

In rural areas in Indonesia, consumption of fleshy food such as meat, poultry and small whole fish with bones, which are readily available sources of haem $\mathrm{Fe}, \mathrm{Zn}$ and preformed vitamin A, is often limited ${ }^{(4)}$ because of economic constraints. Inexpensive, Fe-rich foods, such as tempeh, are available and have been a part of the daily diet of Indonesians. Tempeh is a non-salted fermented soyabean product that contains $2 \cdot 3 \mathrm{mg} \mathrm{Fe} / 100 \mathrm{~g}^{(5)}$ and is consumed as a protein-rich meat substitute by all economic groups.

Hurrell et $a l^{(6)}$ concluded that complete degradation of phytic acid in legumes may increase Fe absorption up to fivefold. This is in agreement with a study showing 
that Fe absorption from fermented tempeh was significantly better than that from soya-flour meals ${ }^{(7)}$ and that the intake of $208 \mathrm{~g}$ of tempeh over $11 \mathrm{~d}$ increased the concentration of $\mathrm{Fe}$ in the liver in Fe-deficient rats, compared with the intake of unfermented soyabean ${ }^{(8)}$. The fermentation process leads to a reduction of phytic acid content and to more absorbable Fe. Another study has shown that the remaining phytic acid content in fresh fermented soyabean (tempeh) is 50\% less than that in raw soyabean and further decreases to $<20 \%$ in cooked tempeh ${ }^{(9)}$.

Tempeh is rich in phyto-oestrogens, which have multiple beneficial effects, but animal studies ${ }^{(10)}$ have shown that high amounts can also have adverse effects on offspring. Such effects have not been observed in human trials and the US Food and Drug Administration recommends an intake of $25 \mathrm{~g}$ of soya protein daily as part of a healthy diet, which corresponds to $125 \mathrm{~g}$ of tempeh ${ }^{(11)}$. A study conducted in Central Java among pregnant women has shown that the daily tempeh intake is only $50 \mathrm{~g}^{(12)}$ and therefore adding tempeh to the usual diet is safe.

To date, relatively little emphasis has been placed on the effectiveness of food-based approaches in the control of ID. Our primary aim was to examine the effect of maternal intervention comprising a daily portion of local fermented soyabean (tempeh) and vitamin C-rich fruits on reducing maternal ID. The effect on birth outcomes was also assessed.

\section{Methods}

\section{Study location and participants}

We carried out the study from November 2007 to October 2008 in thirty-nine villages in two districts, Karanganyar and Demak, of Central Java Province, Indonesia. The distance between the two districts is about $160 \mathrm{~km}$. The twenty-four villages in Karanganyar district are 325-1500 m above sea level, whereas the fifteen villages in Demak district have an elevation of $0-100 \mathrm{~m}$ above sea level. Malaria was not endemic in the study areas. The common diet comprised rice-based meals taken with vegetables and dried salted fish, soya products and occasionally meat.

Pregnant women who attended antenatal clinics in villages were invited to participate in the trial. We also coordinated with the midwives to identify women who had not yet self-reported for prenatal care. The pregnant women identified for the study were asked to gather at the community health centre (Puskesmas) for screening procedures. Requirements for eligibility included: 15-49 years of age; 12-20 weeks of gestational age; no existing severe maternal illness; and predicted singleton neonates. Women were assessed for an estimated gestational age by calculating from the first day of the last menstrual period and were confirmed by palpation on fundal height by a coordinator midwife; physical examination was carried out by a medical doctor from Puskesmas.
The nature and process of the trial were explained to the women at the time of enrolment and only those women who gave written consent were recruited. The ethical and scientific committee for the study of humans of the Faculty of Medicine, University of Indonesia, approved the study protocol. This trial is registered as an International Standard Randomised Controlled Trial (no. ISRCTN13994081).

\section{Procedures}

We conducted a community-based interventional trial with randomization of the two groups: the optimized diet group and the control group. The randomization process was carried out at the village level. Our study was conducted as close as possible to the 'real-life setting' in the community. All women at 12-20 weeks of gestation were recruited without considering their anaemia status. Both groups had free access to receive tablets containing $60 \mathrm{mg}$ of Fe and $250 \mu \mathrm{g}$ of folic acid as part of the Ministry of Health package of prenatal care and/or multiple micronutrient supplements from midwives' clinics. All women at 18-22 weeks of gestation received a single dose of $400 \mathrm{mg}$ albendazole (Kimia Farma, Jakarta, Indonesia) for anthelminthic treatment. Pregnant women allocated to the optimized diet group received supplementary food $6 \mathrm{~d} /$ week.

Primary outcome measures included changes in $\mathrm{Fe}$ concentrations after the optimized diet intervention. We defined anaemia as an $\mathrm{Hb}$ concentration of $<110 \mathrm{~g} / \mathrm{l}^{(13)}$; ID as a plasma ferritin concentration of $<30 \mu \mathrm{g} / \mathrm{l}^{(13)}$ or a plasma-soluble transferrin receptor (TfR) concentration of $>8.5 \mathrm{mg} / \mathrm{l}^{(14)}$; and IDA as concurrent anaemia and ID. Inflammation was indicated when the $\mathrm{C}$-reactive protein (CRP) concentration was $>5 \mathrm{mg} / 1$ and/or $\alpha$-1-acid glycoprotein (AGP) concentration was $>1 \mathrm{~g} / \mathrm{l}^{(15)}$. We also assessed gestational age, birth weight and infant's length. We identified low birth weight as birth weight $<2500 \mathrm{~g}$ ( $\leq 2500 \mathrm{~g}$ was used for scales with $100 \mathrm{~g}$ increments) and preterm birth as gestational age $<37$ weeks. We identified stillbirth as delivery of an infant showing no signs of life movements, breathing or heartbeat after 23 weeks of gestation and early neonatal death as death of a liveborn infant during the first $7 \mathrm{~d}$ after birth.

\section{Blood}

We took samples of $3 \mathrm{ml}$ of venous blood by means of venepuncture at baseline (12-20 weeks of gestation) and at near term (32-36 weeks of gestation). We drew $0.5 \mathrm{ml}$ of blood into Na-EDTA vacuettes for haematological analyses and measured $\mathrm{Hb}$ concentration in blood samples using a haematology analyser (Nihon Kohden MEK-6318K, Tokyo, Japan, or Coulter HmX, Brea, CA, USA). The remaining $2.5 \mathrm{ml}$ was drawn into vacuette heparin tubes (Greiner, Kremsmuenster, Austria) for analyses of plasma ferritin, TfR, CRP and AGP. The tubes were kept in a cooled box with cool packs during transport to the local 
Table 1 Nutrient content in supplementary foods per $100 \mathrm{~g}$

\begin{tabular}{|c|c|c|c|c|c|}
\hline & \multicolumn{2}{|c|}{ Karanganyar ( $n$ 4) } & \multicolumn{2}{|c|}{ Demak ( $n$ 4) } & \multirow[b]{2}{*}{$P+$} \\
\hline & Median & IQR & Median & IQR & \\
\hline Energy (kJ) & $859 \cdot 8$ & $836 \cdot 8-873 \cdot 4$ & $759 \cdot 4$ & $747 \cdot 9-786 \cdot 6$ & 0.021 \\
\hline Protein $(\mathrm{g})$ & $9 \cdot 5$ & $9 \cdot 4-9 \cdot 7$ & 8.9 & $8 \cdot 6-9 \cdot 1$ & 0.020 \\
\hline Fat $(\mathrm{g})$ & $11 \cdot 4$ & $10 \cdot 0-11 \cdot 8$ & $9 \cdot 3$ & $7 \cdot 9-9 \cdot 6$ & 0.042 \\
\hline Carbohydrates (g) & $16 \cdot 0$ & $14 \cdot 5-19 \cdot 8$ & $18 \cdot 0$ & $15 \cdot 0-19 \cdot 5$ & 0.659 \\
\hline $\mathrm{Fe}(\mathrm{mg})$ & $1 \cdot 8$ & $1 \cdot 6-2 \cdot 0$ & $1 \cdot 7$ & $1 \cdot 3-1 \cdot 9$ & 0.386 \\
\hline Vitamin C (mg)‡ & $76 \cdot 5$ & - & $76 \cdot 5$ & - & - \\
\hline
\end{tabular}

IQR, interquartile range.

Median and IQR unless otherwise indicated. Nutrient analyses (energy, protein, fat, carbohydrates and Fe) were conducted from duplicate composite samples of four of both Karanganyar and Demak study areas.

tCalculated using the Mann-Whitney $U$ test.

$\ddagger$ Vitamin $C$ content was taken from the Indonesian food database ${ }^{(5)}$.

laboratory. Within $6 \mathrm{~h}$, plasma was separated by centrifugation (MLW T51.1, Germany) at $2750 \mathrm{rpm}$ and room temperature for $10 \mathrm{~min}$. The plasma was then transferred into Eppendorf Safe Lock vials that were stored at $-7^{\circ} \mathrm{C}$ (for 1 month), then at $-70^{\circ} \mathrm{C}$ until further analyses. Frozen plasma concentrations of ferritin, TfR, CRP and AGP were transported in dry ice to DBS-Tech (Legelshurst, Germany) and measured using an in-house sandwich ELISA technique $^{(16)}$. We used CRP and AGP as a marker of acute and chronic inflammation since ferritin is elevated in the presence of infection or inflammation ${ }^{(17)}$.

\section{Supplementary food for an optimized diet}

The emphasis was on the use of tempeh as the main ingredient of supplementary food for optimizing the diet to provide additional $\mathrm{Fe}$ and vitamin $\mathrm{C}$ sources to improve the Fe bioavailability. The average weekly supplementary food consisted of $600 \mathrm{~g}$ of tempeh, $30 \mathrm{~g}$ of red meat, $30 \mathrm{~g}$ of dried anchovies, $30 \mathrm{~g}$ of chicken liver, $350 \mathrm{~g}$ of guava, $300 \mathrm{~g}$ of papaya and $100 \mathrm{~g}$ of orange. The women were instructed to consume an average of $50 \mathrm{~g}$ of tempeh, $15 \mathrm{~g}$ of dried anchovies/red meat/chicken liver and $50 \mathrm{~g}$ of guava/100 $\mathrm{g}$ of papaya together with their lunch meal, $50 \mathrm{~g}$ of tempeh for snacks in the evening and $50 \mathrm{~g}$ of guava/orange with their dinner meal daily and not to drink tea or coffee within $2 \mathrm{~h}$ of meal time. The daily nutrient composition in the food comprised Fe $3.97 \mathrm{mg}$, vitamin C $173 \mathrm{mg}$ and protein $23 \mathrm{~g}$. Six local recipes of tempeh cooked with different seasoning ingredients were presented in repeating sequence.

Tempeh was purchased from two home industries. We used two brands of soya sauce. Fruit, chicken liver, red meat, dried anchovies and spices were purchased from the local markets. The food was prepared in the study centre and distributed daily until the women gave birth. Cooks were hired from among village women. Each participant received the food in a name-coded plastic box.

Compliance was calculated by expressing the total amount (g) of supplementary food consumed daily as the proportion of the amount assigned to every participant during the intervention period. Uncooked, cooked and leftovers of supplementary food were weighed using food scales with a precision of $\pm 1 \mathrm{~g}$ (Soenle-Waagen $\mathrm{GmbH}$, Murrhardt, Germany or Inotec, Essen, Germany) and calibrated daily using fixed weights by the trained enumerators at the study centre.

Duplicate portions of supplementary food were analysed for energy, protein, fat, carbohydrates and Fe at baseline and endline (Table 1). The analyses were conducted at the Center for Research and Development in Food and Nutrition, Bogor, Indonesia. Vitamin C content was taken from the Indonesian food database ${ }^{(5)}$.

\section{Sensory test}

In May 2007 we conducted a 2-week pilot study in which we provided ten pregnant women of median gestational age 7.5 months with a daily target amount of supplementary food to assess the acceptability of the food and compliance with consumption of the target quantity.

\section{Food intake}

At baseline and endline, two nutritionists interviewed the participants to obtain records of the food intake of the previous day using a quantitative $24 \mathrm{~h}$ recall, except for amounts of the supplementary food that were not recorded at endline. Repeated $24 \mathrm{~h}$ recalls within 1 week were obtained from $30 \%$ of participants selected randomly to validate the variation of energy and nutrient intakes.

\section{Stool}

We collected fresh stool samples in plastic containers to assess the degree and type of parasite infestation. Within $24 \mathrm{~h}$, using the Kato-Katz technique, we conducted an analysis to quantitatively identify the helminth eggs of hookworm, Ascaris lumbricoides and Trichuris trichiuria ${ }^{(18)}$. In addition, we used the Harada-Mori technique, which is more sensitive compared with the Kato-Katz technique ${ }^{(19)}$, to detect living hookworm larvae. We examined the samples at the Laboratory for Parasitology, Sebelas Maret University, Solo, and at the Laboratory for Parasitology, Diponegoro University, Semarang. 


\section{Anthropometry}

We measured height at baseline accurate to $0 \cdot 1 \mathrm{~cm}$ using a microtoise and monthly body weight to the nearest $0 \cdot 1 \mathrm{~kg}$ using an electronic weighing scale (SECA 890, Hamburg, Germany).

A coordinator midwife and a trained nutritionist visited postpartum women and measured their birth weight and body weight using electronic scales (SECA 890) calibrated before measurement at the study centre. Infants' length was measured using a length board (SECA 416 or Shorr, Olney, MD, USA). We attempted to establish birth weight and infants' length within $72 \mathrm{~h}$.

The trained enumerators conducted the interviews and observations through home visits to record socioeconomic status.

\section{Statistical analyses}

With a power of $90 \%$ and a two-sided significance level of $5 \%$, baseline and follow-up data of 168 women would be needed to detect a change in the $\mathrm{Hb}$ concentration of $5 \mathrm{~g} / 1$ and an SD of $10 \mathrm{~g} / \mathrm{l}$ in the optimized diet group relative to the control group. Anticipating a dropout rate of $50 \%$ until delivery, a total of 250 pregnant women were recruited.

We used the Kolmogorov-Smirnov one-sample test to check the normality of data. Data were reported as means and SD for normally distributed variables and as median and interquartile range for non-normally distributed variables. Hb, plasma ferritin, TfR and CRP concentrations and nutrient intake were logarithmically transformed and reported as geometric means and 95\% CI. Continuous Fe and inflammation status was first compared using a $t$ test and then adjusted for potential confounding using univariate analyses. Each model was adjusted for the factors (altitude, maternal gestational week, height, supplement intake) that differed between groups at recruitment, as well as for baseline concentrations of the analyte of interest and for changes in nutrient intake. To test the difference between baseline and endline, the paired $t$ test was used for continuous variables. The Mann-Whitney test was used to examine differences between groups for non-normally distributed variables. The $\chi^{2}$ test or logistic regression with the Forward Wald method was used to examine differences in proportions. A body Fe store was estimated using the following equation ${ }^{(20)}$ :

$$
\begin{aligned}
& \text { Body Fe }(\mathrm{mg} / \mathrm{kg})= \\
& \quad-[\log (\mathrm{TfR} / \text { ferritin ratio })-2 \cdot 8229] / 0 \cdot 1207
\end{aligned}
$$

Body $\mathrm{Fe}>0$ indicates the amount of $\mathrm{Fe}$ in stores and body $\mathrm{Fe}<0$ indicates the deficit in tissue Fe. The effect of inflammation on ferritin is eliminated by multiplying the individual plasma ferritin concentrations of participants in the inflammation group by the respective correction factors. An elevated CRP $>5 \mathrm{mg} / 1$ indicates incubation $\times 0 \cdot 82$; a raised CRP and a raised AGP indicate early convalescence $\times 0 \cdot 19^{(15)}$. There was no participant with an elevated AGP concentration alone in the present study. $P<0.05$ was considered as significant (two-tailed). We used the Statistical Package for the Social Sciences statistical software package version $15 \cdot 0$ (SPSS Institute Inc., Chicago, IL, USA) for statistical analyses. The Nutrisurvey software program was used for entering dietary intake and for converting this information into energy and nutrient intakes on the basis of the Indonesian food database ${ }^{(5)}$.

\section{Results}

Figure 1 shows the trial profile. Of the 310 women who were enrolled, fifty-eight were excluded from the study. The primary reasons for exclusion were the women's refusal to participate and a gestational age of $>20$ weeks. Among the remaining 252 women, data on follow-up blood samples were available for 227 (90\%); six women moved elsewhere, thirteen delivered before blood could be taken at near term, two fetuses died after 28 weeks of gestation, three women refused to give blood and one discontinued the consumption of supplementary food. $\mathrm{Hb}$ and plasma samples were available for 213 and 227 women, respectively, at endline. We included all liveborn infants in the analyses of birth outcomes. Of the 244 women who delivered, $94 \cdot 8 \%$ of birth outcomes were available for the analyses of infants, two were stillbirths, one was lost to follow-up and two infants died within 1 week.

Table 2 shows baseline characteristics related to socioeconomic status, age and nutritional status and Table 3 shows the characteristics for $\mathrm{Fe}$ and inflammation status. Both groups were comparable, except for altitude, gestational age, maternal height and supplement consumption of Fe and folic and/or multiple micronutrient tablets.

We noted these four potential confounders and ensured that they were controlled for in the main outcome analyses. All participants had access to electricity and went for regular checkups to a midwife. None of the women smoked cigarettes, but $84.5 \%$ of the household members (male) did so. Median BMI was normal at $21 \mathrm{~kg} / \mathrm{m}^{2}$. Seventy-six $(30 \cdot 2 \%)$ women were infected lightly with at least one of the three worms assessed, with hookworm infection being the most often detected. The intensity of infection of T. trichiuria was inversely associated with $\mathrm{Hb}$ concentration, although weakly $(r=-0 \cdot 174, P=0 \cdot 006)$. After adjusting for altitude, gestational age, maternal height and supplement intake at baseline, $\mathrm{Hb}$, plasma ferritin and TfR concentrations and body Fe values of Fe status and CRP and AGP concentrations of inflammation status did not differ between the optimized diet and control groups, which showed normal values.

Baseline blood samples were collected at a median gestational age of 14 weeks in the intervention group and at 15 weeks in the control group; endline samples were 


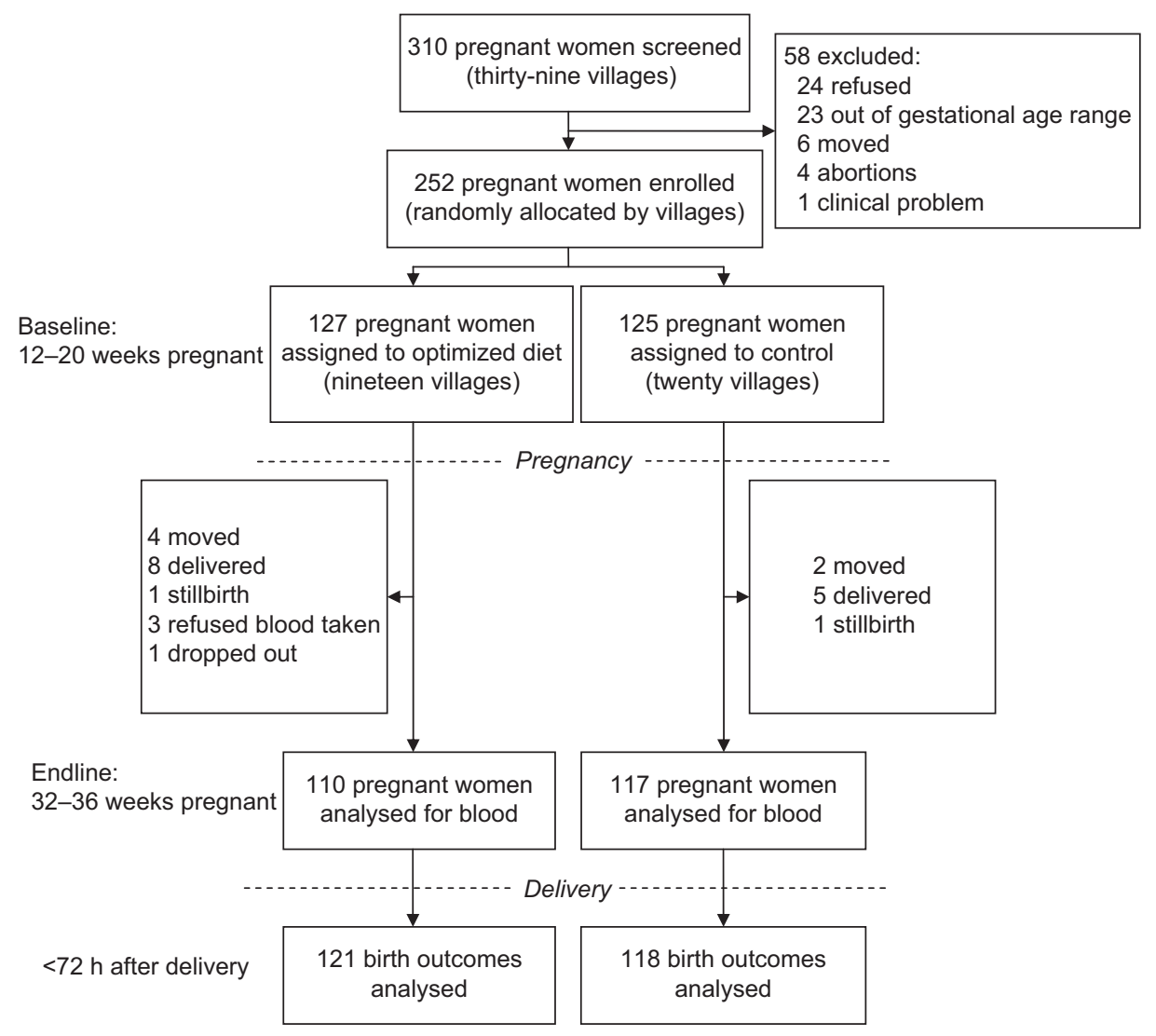

Fig. 1 The study profile

collected at $34 \cdot 7$ weeks in both groups (Table 4). The mean feeding days were 109 (SD 14.8) with a median daily consumption of supplementary food of $231.94 \mathrm{~g}$, with interquartile range of $223 \cdot 96-235 \cdot 62 \mathrm{~g}$. The optimized diet group consumed $96 \cdot 77 \%, 98 \cdot 49 \%, 95 \cdot 68 \%$ and $96 \cdot 05 \%$ of the total amount of tempeh, animal-source food, vitamin C-rich fruit and supplementary food, respectively, provided to them until the second blood assessment. During the intervention, no significant change in $\mathrm{Hb}$ concentration was observed between the groups. Plasma ferritin concentration and body Fe were significantly lower and TfR concentration was significantly higher in both groups. When data were analysed separately for Fe-deficient and Fe-replete women, a significantly smaller decrease in plasma ferritin concentrations was observed in Fe-deficient women but not in Fe-replete women in the optimized diet group compared with the control group $(1 \cdot 42,95 \%$ CI $1 \cdot 16,1 \cdot 75 \mu \mathrm{g} / 1 v \cdot 1 \cdot 85,95 \%$ CI $1 \cdot 55,2 \cdot 2 \mu \mathrm{g} / 1$, respectively; $P=0 \cdot 046$ ). Similarly, compared with the control group, the optimized diet group showed a smaller decrease in $\mathrm{Hb}(1.02,95 \%$ CI $0.98,1.07 \mathrm{~g} / \mathrm{l}$, $P=0.058)$ and body Fe $(2 \cdot 57,95 \%$ CI $1 \cdot 71,3 \cdot 43 \mathrm{mg} / \mathrm{kg}$, $P=0 \cdot 073)$ concentrations. By contrast, in Fe-replete women no differences in Fe status were observed between the optimized diet and control groups. We recorded no significant difference in optimized diet $v$. control groups with regard to acute inflammation, whereas a larger decrease was seen in Fe-replete women for chronic inflammation in the optimized diet group compared with the control group $(0 \cdot 15,95 \%$ CI $0 \cdot 12,0 \cdot 18 \mathrm{~g} / 1 v \cdot 0 \cdot 09,95 \%$ CI $0 \cdot 06,0 \cdot 12 \mathrm{~g} / \mathrm{l}$, respectively; $P=0 \cdot 046)$.

Thirty-six (16.9\%), eighty-six $(37 \cdot 9 \%)$, six $(2 \cdot 6 \%)$ and fourteen $(6.6 \%)$ women had anaemia, ID, tissue ID and IDA, respectively (Table 5). A few women (0.9\%) suffered from chronic inflammation and thirty-nine (17.2\%) suffered from acute inflammation, which was of low intensity. At near term, the prevalence of ID, tissue ID and IDA increased in both groups. By logistic regression, there was no significant time $\times$ treatment interaction for anaemia, ID, tissue ID and IDA. The prevalence of chronic and acute inflammation remained virtually unchanged in the two groups.

All but one pregnant woman took Fe-containing supplements; $13 \cdot 3 \%$ took only Fe-folate supplements from government programmes (60 mg Fe/tablet), 46.1\% took multiple micronutrients containing Fe (12-118 mg $\mathrm{Fe} / \mathrm{tablet}$ ) and the remaining $40 \cdot 2 \%$ took both supplements. The total intake of Fe from supplements was comparable between the optimized diet and control groups (2502 (SD 177) mg $v .2920$ (SD 189) mg, respectively; $P=0 \cdot 127)$. Only thirteen women had worm infections at endline, with six being infected with hookworm and seven having T. trichiuria (data not shown). 
Table 2 Baseline characteristics of study participants

\begin{tabular}{|c|c|c|c|c|c|}
\hline \multirow[b]{2}{*}{ Characteristic } & \multicolumn{2}{|c|}{ Optimized diet ( $n$ 127) } & \multicolumn{2}{|c|}{ Control ( $n$ 125) } & \multirow[b]{2}{*}{$P+$} \\
\hline & $\%$ or median & IQR & $\%$ or median & IQR & \\
\hline \multicolumn{5}{|l|}{ Altitude (m; \%) } & 0.016 \\
\hline $0-500$ & $44 \cdot 9$ & & 60 & & \\
\hline $501-1500$ & $55 \cdot 1$ & & 40 & & \\
\hline Number of household members & 4 & $3-6$ & 4 & $3-6$ & 0.690 \\
\hline \multicolumn{5}{|l|}{ Defecating place $(\%)$} & $0 \cdot 118$ \\
\hline Latrine & $66 \cdot 9$ & & $54 \cdot 4$ & & \\
\hline River/yard/bush & $26 \cdot 0$ & & $34 \cdot 4$ & & \\
\hline Pit & $7 \cdot 1$ & & $11 \cdot 2$ & & \\
\hline \multicolumn{5}{|l|}{ Age (years; \%) } & $0 \cdot 271$ \\
\hline$<20$ & $11 \cdot 0$ & & $10 \cdot 4$ & & \\
\hline $20-24$ & $26 \cdot 8$ & & $28 \cdot 8$ & & \\
\hline $25-29$ & $37 \cdot 8$ & & $28 \cdot 0$ & & \\
\hline $30-34$ & $20 \cdot 5$ & & $23 \cdot 2$ & & \\
\hline$\geq 35$ & $3 \cdot 9$ & & $9 \cdot 6$ & & \\
\hline \multicolumn{5}{|l|}{ Schooling (years; \%) } & 0.743 \\
\hline None or primary $(0-6)$ & $50 \cdot 4$ & & $45 \cdot 6$ & & \\
\hline Secondary $(7-9)$ & $33 \cdot 1$ & & $36 \cdot 8$ & & \\
\hline Higher education $(\geq 10)$ & $16 \cdot 5$ & & $17 \cdot 6$ & & \\
\hline \multicolumn{5}{|l|}{ Occupation (\%) } & 0.409 \\
\hline Housewife & $50 \cdot 4$ & & $53 \cdot 6$ & & \\
\hline Farming & $30 \cdot 7$ & & $26 \cdot 4$ & & \\
\hline Salaried & $7 \cdot 1$ & & $3 \cdot 2$ & & \\
\hline Waged labour & $3 \cdot 1$ & & $6 \cdot 4$ & & \\
\hline Entrepreneur & $8 \cdot 7$ & & $10 \cdot 4$ & & \\
\hline Gestational age (weeks) & 14 & $13 \cdot 0-16 \cdot 0$ & 15 & $13 \cdot 5-16 \cdot 8$ & 0.014 \\
\hline Parity & 2 & $1-2$ & 2 & $1-3$ & 0.923 \\
\hline \multicolumn{5}{|l|}{ Number of pregnancy checkups (times; \%) } & $0 \cdot 30$ \\
\hline 1 & $23 \cdot 6$ & & $17 \cdot 6$ & & \\
\hline 2 & $36 \cdot 2$ & & $30 \cdot 4$ & & \\
\hline 3 & $29 \cdot 1$ & & $37 \cdot 6$ & & \\
\hline$>3$ & $11 \cdot 0$ & & $14 \cdot 4$ & & \\
\hline \multicolumn{5}{|l|}{ Supplement consumption (capsules/tablets; \%) } & 0.003 \\
\hline 0 & $18 \cdot 1$ & & $6 \cdot 4$ & & \\
\hline $1-30$ & $66 \cdot 1$ & & $65 \cdot 6$ & & \\
\hline$>30$ & $15 \cdot 7$ & & $28 \cdot 0$ & & \\
\hline \multicolumn{6}{|l|}{ Height $(\mathrm{cm})$} \\
\hline Mean & $150 \cdot 7$ & & $152 \cdot 8$ & & 0.001 \\
\hline SD & $5 \cdot 6$ & & $5 \cdot 2$ & & \\
\hline BMI $\left(\mathrm{kg} / \mathrm{m}^{2}\right)$ & $21 \cdot 0$ & $19 \cdot 3-23 \cdot 0$ & $21 \cdot 3$ & $19 \cdot 4-23 \cdot 4$ & 0.641 \\
\hline$<18.5 \mathrm{~kg} / \mathrm{m}^{2}$ & $13 \cdot 4$ & & $13 \cdot 6$ & & 0.960 \\
\hline \multicolumn{6}{|l|}{ Helminth infestation (\%) } \\
\hline Ascaris lumbricoides & $2 \cdot 4$ & & $0 \cdot 0$ & & $0 \cdot 247$ \\
\hline Trichuris trichiuria & $6 \cdot 3$ & & $7 \cdot 2$ & & 0.776 \\
\hline Hookworm & $21 \cdot 3$ & & $26 \cdot 4$ & & 0.338 \\
\hline
\end{tabular}

$\mathrm{IQR}$, interquartile range.

$\%$ or median and IQR, unless otherwise indicated.

tCalculated using the $\chi^{2}$ test for categorical variables, the Mann-Whitney $U$ test for non-normally distributed variables or the $t$ test for normally distributed variables.

There was no change in food availability in the study area for the duration of the study (Table 6). Intake of Fe increased significantly in the optimized diet group; intake of protein increased significantly in both groups. When the supplementary food was excluded from the analyses, the changes in nutrient intake did not differ between groups, except for the changes in vitamin $\mathrm{C}$ intake. The median intake of tempeh was $56 \mathrm{~g}$.

The mean feeding days until delivery were 136 (SD 21) $\mathrm{d}$ and the mean supplementary food consumption was 30703.81 (sD 5493.23) g. None of the differences shown in birth outcomes were significant (Table 7). Although birth weight and length were taken later $(P=0 \cdot 036)$ in the control group compared with the optimized diet group, this difference is unlikely to affect birth size measurements of the infants. Compared with the control group, the optimized diet group tended to have a higher percentage of low birth weight, which was mainly because of a shorter mean gestational age in the optimized diet group compared with the control group (37.6 (SD 2.7) weeks $v$. 39.2 (SD 1.6) weeks, respectively; $P=0.064)$ among the low birth weight infants. We recorded no differences between the groups with regard to reported complications during pregnancy, such as prolonged labour, retained placenta and postpartum haemorrhage (data not shown). 
Table 3 Maternal iron and inflammation status at baseline with two analytic models for differences between group means

\begin{tabular}{|c|c|c|c|c|c|c|c|c|}
\hline \multirow[b]{2}{*}{ Indicator } & \multicolumn{2}{|c|}{ Optimized diet ( $n$ 127) } & \multicolumn{2}{|c|}{ Control (n 125) } & \multirow[b]{2}{*}{$\begin{array}{l}\text { Unadjusted } \\
\text { difference }\end{array}$} & \multirow[b]{2}{*}{$95 \% \mathrm{Cl}$} & \multirow[b]{2}{*}{$\begin{array}{l}\text { Adjusted } \\
\text { differencet }\end{array}$} & \multirow[b]{2}{*}{$95 \% \mathrm{Cl}$} \\
\hline & $\begin{array}{l}\text { Geometric } \\
\text { mean }\end{array}$ & SD & $\begin{array}{l}\text { Geometric } \\
\text { mean }\end{array}$ & SD & & & & \\
\hline $\begin{array}{l}\mathrm{Hb}(\mathrm{g} / \mathrm{l} ; n 123) \\
\text { Ferritin ( } \mu \mathrm{g} / \mathrm{l})\end{array}$ & $124 \cdot 22$ & $1 \cdot 13$ & $118 \cdot 90$ & $1 \cdot 14$ & 0.96 & $0.93,0.99^{\star *}$ & 0.98 & $0.95,1.01$ \\
\hline All women & $37 \cdot 77$ & 1.94 & $38 \cdot 12$ & 1.95 & $1 \cdot 01$ & $0 \cdot 86,1 \cdot 19$ & 1.02 & $0 \cdot 86,1 \cdot 21$ \\
\hline Women without inflammation ( $n$ 106) & $37 \cdot 96$ & 1.96 & $39 \cdot 28$ & 1.93 & $1 \cdot 03$ & $0 \cdot 86,1 \cdot 23$ & $1 \cdot 06$ & $0 \cdot 88,1 \cdot 28$ \\
\hline $\begin{array}{l}\text { Transferrin receptor (mg/l) } \\
\text { Body Fe (mg/kg body weight; mean) }\end{array}$ & $5 \cdot 32$ & $1 \cdot 22$ & $5 \cdot 08$ & $1 \cdot 27$ & 0.95 & $0 \cdot 90,1 \cdot 01$ & 0.95 & $0 \cdot 90,1 \cdot 0$ \\
\hline All women & $5 \cdot 58$ & $2 \cdot 80$ & $5 \cdot 79$ & $2 \cdot 91$ & $0 \cdot 20$ & $-0.50,0.91$ & $0 \cdot 27$ & $-0 \cdot 46,1 \cdot 0$ \\
\hline Women without inflammation ( $n$ 106) & $5 \cdot 59$ & $2 \cdot 90$ & $5 \cdot 97$ & $2 \cdot 92$ & $0 \cdot 37$ & $-0 \cdot 42,1 \cdot 16$ & 0.52 & $-0.29,1 \cdot 34$ \\
\hline C-reactive protein $(\mathrm{mg} / \mathrm{l})$ & $1 \cdot 60$ & $3 \cdot 22$ & $1 \cdot 56$ & 3.03 & 0.98 & $0 \cdot 74,1 \cdot 30$ & 0.98 & $0.73,1.31$ \\
\hline$\alpha$-1-acid glycoprotein (g/l; mean) & 0.58 & $0 \cdot 13$ & 0.56 & $0 \cdot 15$ & -0.02 & $-0.05,0.02$ & 0.01 & $-0.03,0.04$ \\
\hline
\end{tabular}

Geometric mean and SD unless otherwise indicated.

${ }^{\star \star} P<0.01$ for difference between optimized diet and control group ( $t$ test).

tAdjusted difference for altitude, gestational week, maternal height, supplement intakes at baseline (analysis of covariance).

Table 4 Effect on iron and inflammation status as a result of consuming the optimized diet

\begin{tabular}{|c|c|c|c|c|c|}
\hline & \multicolumn{2}{|c|}{ Optimized diet } & \multicolumn{2}{|c|}{ Control } & \multirow[b]{2}{*}{$P+$} \\
\hline & Geometric mear & SD & Geometric mean & SD & \\
\hline \multicolumn{6}{|c|}{$(n 110)$} \\
\hline Feeding days until the second blood assessment & $109 \cdot 06$ & $14 \cdot 79$ & - & - & - \\
\hline Total supplementary food given $(\mathrm{g}) \ddagger$ & 26508.01 & $3639 \cdot 34$ & _ & - & - \\
\hline Tempeh $(\mathrm{g}) \ddagger$ & $10671 \cdot 40$ & $1565 \cdot 18$ & - & - & - \\
\hline Animal-source food $(\mathrm{g}) \ddagger$ & $1435 \cdot 67$ & $210 \cdot 93$ & - & _ & - \\
\hline Vitamin C-rich fruit $(\mathrm{g}) \ddagger$ & $14400 \cdot 94$ & $1940 \cdot 28$ & - & - & - \\
\hline Total supplementary food consumed $(\mathrm{g}) \ddagger$ & $24639 \cdot 20$ & $3809 \cdot 72$ & - & - & - \\
\hline Tempeh $(\mathrm{g}) \ddagger$ & $9672 \cdot 22$ & $1946 \cdot 77$ & _ & - & - \\
\hline Animal-source food $(\mathrm{g}) \ddagger$ & $1347 \cdot 21$ & $247 \cdot 04$ & - & - & - \\
\hline Vitamin C-rich fruit $(\mathrm{g}) \ddagger$ & $13619 \cdot 77$ & $1921 \cdot 85$ & - & _ & _ \\
\hline Gestational age (weeks) & \multicolumn{2}{|c|}{$(n 110)$} & \multicolumn{2}{|c|}{$(n 117)$} & \\
\hline Baseline§ & $14 \cdot 0$ & $13 \cdot 0-16 \cdot 0$ & $15 \cdot 0$ & $13 \cdot 45-16 \cdot 75$ & 0.014 \\
\hline Near term§ & $34 \cdot 71$ & $33 \cdot 86-35 \cdot 19$ & $34 \cdot 71$ & $34 \cdot 0-35 \cdot 68$ & 0.228 \\
\hline $\mathrm{Hb}(\mathrm{g} / \mathrm{l})$ & \multicolumn{2}{|c|}{$(n$ 103) } & \multicolumn{2}{|c|}{$(n 110)$} & \\
\hline Baseline & $125 \cdot 31$ & $1 \cdot 14$ & $118 \cdot 71$ & $1 \cdot 14$ & \\
\hline Near term & $121 \cdot 76$ & $1 \cdot 13$ & $117 \cdot 41$ & $1 \cdot 11$ & \\
\hline Change $(95 \% \mathrm{Cl})$ & 1.03 & $1 \cdot 00,1 \cdot 06^{\star}$ & $1 \cdot 01$ & $0.99,1.04$ & 0.412 \\
\hline Fe deficient (ferritin $<30 \mu \mathrm{g} / \mathrm{l}$ ) & \multicolumn{2}{|c|}{$(n 36)$} & \multicolumn{2}{|c|}{$(n$ 43) } & \\
\hline Baseline & $125 \cdot 69$ & 1.09 & $117 \cdot 68$ & $1 \cdot 13$ & \\
\hline Near term & $122 \cdot 83$ & $1 \cdot 14$ & 113.63 & $1 \cdot 10$ & \\
\hline Change $(95 \% \mathrm{Cl})$ & 1.02 & $0.98,1.07$ & $1 \cdot 04$ & $1 \cdot 00,1 \cdot 07^{*}$ & 0.058 \\
\hline Fe replete (ferritin $\geq 30 \mu \mathrm{g} / \mathrm{l}$ ) & \multicolumn{2}{|c|}{$(n 67)$} & \multicolumn{2}{|c|}{$(n 67)$} & \\
\hline Baseline & $125 \cdot 11$ & $1 \cdot 15$ & $119 \cdot 37$ & $1 \cdot 15$ & \\
\hline Near term & $121 \cdot 20$ & $1 \cdot 13$ & $119 \cdot 87$ & $1 \cdot 12$ & \\
\hline Change $(95 \% \mathrm{Cl})$ & 1.03 & $0.99,1.07$ & $1 \cdot 0$ & $0.96,1.03$ & 0.418 \\
\hline Ferritin $(\mu \mathrm{g} / \mathrm{l})$ & \multicolumn{2}{|c|}{$(n 110)$} & \multicolumn{2}{|c|}{$(n$ 117) } & \\
\hline Baseline & 38.19 & 1.92 & $38 \cdot 26$ & 1.95 & \\
\hline Near term & $16 \cdot 47$ & $1 \cdot 81$ & $15 \cdot 41$ & 1.90 & \\
\hline Change $(95 \% \mathrm{Cl})$ & $2 \cdot 32$ & $2 \cdot 03,2 \cdot 65^{\star \star \star}$ & $2 \cdot 48$ & $2 \cdot 20,2 \cdot 80^{\star \star \star}$ & $0 \cdot 180$ \\
\hline Fe deficient (ferritin $<30 \mu \mathrm{g} / \mathrm{l}$ ) & \multicolumn{2}{|r|}{$2 \cdot 03,2 \cdot 05$} & \multicolumn{2}{|c|}{$(n 46)$} & \\
\hline Baseline & $19 \cdot 57$ & $1 \cdot 48$ & $19 \cdot 76$ & $1 \cdot 48$ & \\
\hline Near term & $13 \cdot 78$ & 1.91 & $10 \cdot 70$ & $1 \cdot 72$ & \\
\hline Change $(95 \% \mathrm{Cl})$ & $1 \cdot 42$ & $1 \cdot 16,1 \cdot 75^{\star \star}$ & $1 \cdot 85$ & $1 \cdot 55,2 \cdot 20^{\star \star \star}$ & 0.046 \\
\hline Fe replete (ferritin $\geq 30 \mu \mathrm{g} / \mathrm{l}$ ) & \multicolumn{2}{|c|}{$(n 70)$} & \multicolumn{2}{|c|}{$(n 71)$} & \\
\hline Baseline & $55 \cdot 96$ & $1 \cdot 52$ & $58 \cdot 69$ & 1.50 & \\
\hline Near term & $18 \cdot 23$ & $1 \cdot 72$ & $19 \cdot 51$ & $1 \cdot 81$ & \\
\hline Change $(95 \% \mathrm{Cl})$ & 3.07 & $2 \cdot 67,3 \cdot 52^{\star \star *}$ & 3.01 & $2 \cdot 60,3 \cdot 48^{\star \star \star}$ & 0.914 \\
\hline Transferrin receptor (mg/l) & \multicolumn{2}{|c|}{$(n 110)$} & \multicolumn{2}{|c|}{$(n 117)$} & \\
\hline Baseline & $5 \cdot 29$ & $1 \cdot 23$ & $5 \cdot 10$ & 1.27 & \\
\hline Near term & $7 \cdot 35$ & $1 \cdot 30$ & $7 \cdot 48$ & $1 \cdot 31$ & \\
\hline Change $(95 \% \mathrm{Cl})$ & 0.72 & $0 \cdot 69,0 \cdot 75^{\star \star \star}$ & 0.68 & $0 \cdot 65,0 \cdot 71^{\star * *}$ & $0 \cdot 119$ \\
\hline Fe deficient (ferritin $<30 \mu \mathrm{g} / \mathrm{l}$ ) & \multicolumn{2}{|c|}{$(n 40)$} & \multicolumn{2}{|c|}{$(n 46)$} & \\
\hline Baseline & $5 \cdot 78$ & $1 \cdot 23$ & $5 \cdot 67$ & $1 \cdot 30$ & \\
\hline Near term & $8 \cdot 31$ & $1 \cdot 28$ & $8 \cdot 27$ & $1 \cdot 26$ & \\
\hline Change $(95 \% \mathrm{Cl})$ & $0 \cdot 70$ & $0 \cdot 65,0 \cdot 74^{\star \star \star}$ & 0.69 & $0 \cdot 64,0 \cdot 73^{\star \star \star}$ & $0 \cdot 811$ \\
\hline
\end{tabular}




\begin{tabular}{|c|c|c|c|c|c|}
\hline & \multicolumn{2}{|c|}{ Optimized diet } & \multicolumn{2}{|c|}{ Control } & \multirow[b]{2}{*}{$P+$} \\
\hline & Geometric mear & SD & Geometric mean & SD & \\
\hline Fe replete (ferritin $\geq 30 \mu \mathrm{g} / \mathrm{l}$ ) & \multicolumn{2}{|c|}{$(n 70)$} & \multicolumn{2}{|c|}{$(n 71)$} & \\
\hline Baseline & 5.03 & $1 \cdot 21$ & $4 \cdot 76$ & $1 \cdot 22$ & \\
\hline Near term & $6 \cdot 85$ & $1 \cdot 28$ & $7 \cdot 01$ & $1 \cdot 32$ & \\
\hline Change $(95 \% \mathrm{Cl})$ & $0 \cdot 73$ & $0 \cdot 70,0 \cdot 77^{\star \star \star}$ & 0.68 & $0.64,0.72^{\star \star \star}$ & 0.072 \\
\hline Body Fe (mg/kg body weight) & \multicolumn{2}{|c|}{$(n) 110$} & \multicolumn{2}{|c|}{ ( $(n 117$} & \\
\hline Baseline & $5 \cdot 64$ & $2 \cdot 77$ & $5 \cdot 79$ & $2 \cdot 91$ & \\
\hline Near term $\ddagger$ & $1 \cdot 43$ & $2 \cdot 65$ & $1 \cdot 13$ & $2 \cdot 95$ & \\
\hline Change $(95 \% \mathrm{Cl})$ & $4 \cdot 21$ & $3 \cdot 68,4 \cdot 74^{\star \star \star}$ & $4 \cdot 65$ & $4 \cdot 14,5 \cdot 16^{\star \star \star}$ & $0 \cdot 109$ \\
\hline Fe deficient (ferritin $<30 \mu \mathrm{g} / \mathrm{l}$ ) & \multicolumn{2}{|c|}{$(n 40)$} & \multicolumn{2}{|c|}{$(n 46)$} & \\
\hline Baselineł & $2 \cdot 92$ & $1 \cdot 88$ & 3.03 & 2.03 & \\
\hline Near term $\ddagger$ & 0.35 & $2 \cdot 74$ & -0.54 & $2 \cdot 47$ & \\
\hline Change $(95 \% \mathrm{Cl})$ & $2 \cdot 57$ & $1 \cdot 71,3 \cdot 43^{\star \star *}$ & 3.56 & $2 \cdot 80,4 \cdot 33^{\star \star \star}$ & 0.073 \\
\hline Fe replete (ferritin $\geq 30 \mu \mathrm{g} / \mathrm{l}$ ) & \multicolumn{2}{|c|}{$(n 70)$} & \multicolumn{2}{|c|}{$(n 71)$} & \\
\hline Baselineł & $7 \cdot 20$ & $1 \cdot 83$ & $7 \cdot 57$ & $1 \cdot 77$ & \\
\hline Near term $\ddagger$ & $2 \cdot 06$ & $2 \cdot 41$ & $2 \cdot 22$ & $2 \cdot 74$ & \\
\hline Change $(95 \% \mathrm{Cl})$ & $5 \cdot 15$ & $4 \cdot 58,5 \cdot 72^{\star \star \star}$ & $5 \cdot 35$ & $4 \cdot 72,5 \cdot 99^{\star \star \star}$ & 0.502 \\
\hline C-reactive protein $(\mathrm{mg} / \mathrm{l})$ & \multicolumn{2}{|c|}{$(n 110)$} & \multicolumn{2}{|c|}{$(n 117)$} & \\
\hline Baseline & 1.59 & $3 \cdot 34$ & $1 \cdot 57$ & 3.04 & \\
\hline Near term & $1 \cdot 26$ & $3 \cdot 47$ & $1 \cdot 48$ & $3 \cdot 18$ & \\
\hline Change $(95 \% \mathrm{Cl})$ & $1 \cdot 27$ & $1 \cdot 03,1 \cdot 56^{*}$ & $1 \cdot 06$ & $0 \cdot 86,1 \cdot 29$ & $0 \cdot 125$ \\
\hline Fe deficient (ferritin $<30 \mu \mathrm{g} / \mathrm{l}$ ) & \multicolumn{2}{|c|}{$(n 40)$} & \multicolumn{2}{|c|}{$(n 46)$} & \\
\hline Baseline & 1.92 & 3.44 & $1 \cdot 54$ & 3.32 & \\
\hline Near term & $1 \cdot 52$ & 3.09 & $1 \cdot 26$ & $2 \cdot 97$ & \\
\hline Change $(95 \% \mathrm{Cl})$ & $1 \cdot 27$ & $0.93,1.72$ & $1 \cdot 23$ & $0.91,1.66$ & 0.656 \\
\hline Fe replete (ferritin $\geq 30 \mu \mathrm{g} / \mathrm{l}$ ) & \multicolumn{2}{|c|}{$(n 70)$} & \multicolumn{2}{|c|}{$(n 71)$} & \\
\hline Baseline & $1 \cdot 43$ & 3.27 & $1 \cdot 58$ & $2 \cdot 88$ & \\
\hline Near term & $1 \cdot 13$ & $3 \cdot 68$ & $1 \cdot 65$ & $3 \cdot 30$ & \\
\hline Change $(95 \% \mathrm{Cl})$ & $1 \cdot 26$ & $0.95,1.68$ & 0.96 & $0 \cdot 73,1 \cdot 25$ & 0.085 \\
\hline$\alpha$-1-acid glycoprotein $(\mathrm{g} / \mathrm{l})$ & \multicolumn{2}{|c|}{$(n$ 110) } & \multicolumn{2}{|c|}{$(n$ 117) } & \\
\hline Baseline‡ & 0.59 & $0 \cdot 13$ & 0.57 & 0.14 & \\
\hline Near term $\ddagger$ & 0.45 & 0.11 & 0.45 & $0 \cdot 12$ & \\
\hline Change $(95 \% \mathrm{Cl})$ & $0 \cdot 13$ & $0 \cdot 11,0 \cdot 16^{\star \star \star}$ & $0 \cdot 12$ & $0 \cdot 09,0 \cdot 14^{\star \star \star}$ & $0 \cdot 350$ \\
\hline Fe deficient (ferritin $<30 \mu \mathrm{g} / \mathrm{l}$ ) & \multicolumn{2}{|c|}{$(n$ 40) } & \multicolumn{2}{|c|}{$(n$ 46) } & \\
\hline Baseline $\neq$ & 0.58 & $0 \cdot 11$ & 0.59 & 0.17 & \\
\hline Near term $\ddagger$ & 0.47 & $0 \cdot 11$ & 0.44 & $0 \cdot 11$ & \\
\hline Change $(95 \% \mathrm{Cl})$ & $0 \cdot 11$ & $0 \cdot 07,0 \cdot 15^{\star \star \star}$ & $0 \cdot 15$ & $0 \cdot 11,0 \cdot 20^{\star \star \star}$ & $0 \cdot 191$ \\
\hline Fe replete (ferritin $\geq 30 \mu \mathrm{g} / \mathrm{l}$ ) & \multicolumn{2}{|r|}{ (20, } & \multicolumn{2}{|c|}{$(n 71)$} & \\
\hline Baselineł & 0.59 & $0 \cdot 14$ & 0.55 & $0 \cdot 12$ & \\
\hline Near term $\ddagger$ & $0 \cdot 44$ & $0 \cdot 11$ & 0.46 & $0 \cdot 12$ & \\
\hline Change $(95 \% \mathrm{Cl})$ & $0 \cdot 15$ & $0 \cdot 12,0 \cdot 18^{\star \star \star}$ & 0.09 & $0 \cdot 06,0 \cdot 12^{\star \star \star}$ & 0.032 \\
\hline
\end{tabular}

Geometric mean and SD unless otherwise indicated.

${ }^{\star} P<0.05,{ }^{* \star} P<0.01,{ }^{\star * \star} P<0.001$ for significant change from baseline (paired $t$ test).

tAdjusted for baseline factors: altitude, gestational week, maternal height and supplement intake; Hb concentration, plasma ferritin, soluble transferrin receptor, C-reactive protein and $\alpha-1$-acid glycoprotein concentrations; and changes in energy, protein, fat, carbohydrates, Fe and vitamin $\mathrm{C}$ intakes (analysis of covariance).

¥Mean and SD.

$\S$ Median and interquartile range; $P$ values were calculated using the Mann-Whitney $U$ test.

\section{Discussion}

Consumption of the optimized diet with fermented soyabean (tempeh) and vitamin C-rich fruit in the present study had no effect overall in preventing the worsening of Fe status in Indonesian pregnant women; only in women with ID at baseline could a positive effect on ferritin be found. Our provision of $100 \mathrm{~g}$ of tempeh daily, plus a small amount of animal-source food (small dried fish, meat and liver) with fruit rich in vitamin $\mathrm{C}$, was expected to increase both $\mathrm{Fe}$ intake and absorption. We estimated that the higher intake of $\mathrm{Fe}$ in our intervention $(>3.0 \mathrm{mg}$ of non-haem $\mathrm{Fe} / \mathrm{d},>0 \cdot 2 \mathrm{mg}$ of haem $\mathrm{Fe} / \mathrm{d}$, the improvement in Fe absorption ( $>130 \mathrm{mg}$ of vitamin $\mathrm{C} / \mathrm{d}$, a small amount of meat) and the reduced intake of inhibitors (black tea at meals) could increase the absorbed Fe from $0.4 \mathrm{mg} / \mathrm{d} \quad(8 \mathrm{mg} \times 5 \%)$ to $1.68 \mathrm{mg} / \mathrm{d} \quad(11.2 \mathrm{mg} \times 15 \%)$, assuming an average intake of $8 \mathrm{mg}$ of $\mathrm{Fe} / \mathrm{d}$ in the usual diet and an improvement in absorption from $5 \%$ to $15 \%$. This is not an exact estimation, but $1.68 \mathrm{mg}$ of absorbed $\mathrm{Fe} / \mathrm{d}$ could be enough to provide pregnant women with their daily $\mathrm{Fe}$ requirements ${ }^{(21)}$. Quantitative measurements of body Fe based on the ratio of TfR to ferritin can be used to calculate the Fe absorption in women, including pregnant women ${ }^{(20)}$. Compared with the control group, women receiving supplementary food had an overall smaller decline of $0.44 \mathrm{mg} / \mathrm{kg}$ of body Fe. With an average body weight of $50 \mathrm{~kg}$, this corresponds to $22 \mathrm{mg}$ 
Table 5 Proportion of women with anaemia and low iron stores

\begin{tabular}{|c|c|c|c|c|c|}
\hline & \multicolumn{2}{|c|}{ Optimized diet ( $n$ 110) } & \multicolumn{2}{|c|}{ Control ( $n$ 117) } & \multirow[b]{2}{*}{$P+$} \\
\hline & $n$ & $\%$ & $n$ & $\%$ & \\
\hline Anaemia $(\mathrm{Hb}<110 \mathrm{~g} / \mathrm{l})$ & 103 & & 110 & & $0 \cdot 303$ \\
\hline Baseline & 11 & $10 \cdot 7$ & 25 & $22 \cdot 7$ & \\
\hline Near term & 19 & $18 \cdot 4$ & 21 & $19 \cdot 1$ & \\
\hline Depleted Fe stores (ferritin $<30 \mu \mathrm{g} / \mathrm{l}$ ) & & & & & $0 \cdot 70$ \\
\hline Baseline & 40 & $36 \cdot 4$ & 46 & $39 \cdot 3$ & \\
\hline Near term & 88 & $80 \cdot 0$ & 99 & $84 \cdot 6$ & \\
\hline Fe deficiency $(\mathrm{TfR}>8.5 \mathrm{mg} / \mathrm{l})$ & & & & & $0 \cdot 798$ \\
\hline Baseline & 3 & $2 \cdot 7$ & 3 & $2 \cdot 6$ & \\
\hline Near term & 30 & $27 \cdot 3$ & 37 & $31 \cdot 6$ & \\
\hline Tissue Fe deficit (body $\mathrm{Fe}<0 \mathrm{mg} / \mathrm{kg}$ ) & & & & & 0.373 \\
\hline Baseline & 3 & $2 \cdot 7$ & 5 & $4 \cdot 3$ & \\
\hline Near term & 35 & $31 \cdot 8$ & 44 & $37 \cdot 6$ & \\
\hline Fe-deficiency anaemia $(\mathrm{Hb}<110 \mathrm{~g} / \mathrm{l}$ and ferritin $<12 \mu \mathrm{g} / \mathrm{l})$ & 105 & & 110 & & 0.253 \\
\hline Baseline & 3 & $2 \cdot 9$ & 11 & $10 \cdot 0$ & \\
\hline Near term & 17 & $16 \cdot 2$ & 20 & $18 \cdot 2$ & \\
\hline Acute inflammation (CRP > $>5 \mathrm{mg} / \mathrm{l}$ ) & & & & & 0.90 \\
\hline Baseline & 20 & $18 \cdot 2$ & 19 & $16 \cdot 2$ & \\
\hline Near term & 14 & $12 \cdot 7$ & 17 & $14 \cdot \overline{5}$ & \\
\hline Chronic inflammation (AGP >1 g/l) & & & & & 0.096 \\
\hline Baseline & 0 & 0.0 & 2 & $1 \cdot 7$ & \\
\hline Near term & 0 & $0 \cdot 0$ & 0 & $0 \cdot 0$ & \\
\hline
\end{tabular}

TfR, soluble transferrin receptor; CRP, C-reactive protein; AGP, $\alpha$-1-acid glycoprotein.

tCalculated using logistic regression analysis (the Forward Wald method) with treatment $\times$ time interaction, controlled for altitude, gestational week, maternal height and supplement intake at baseline and changes in energy, protein, fat, carbohydrates, $\mathrm{Fe}$ and vitamin C intakes.

Table 6 Daily intakes of macronutrients, iron and vitamin $C$ and change from baseline to endline of intervention in participants who answered $24 \mathrm{~h}$ recall questionnaire

\begin{tabular}{|c|c|c|c|c|c|}
\hline & \multicolumn{2}{|c|}{ Optimized diet ( $n$ 108) } & \multicolumn{2}{|c|}{ Control (n 114) } & \multirow[b]{2}{*}{$P+$} \\
\hline & Geometric mean & SD or $95 \% \mathrm{Cl}$ & Geometric mean & SD or $95 \% \mathrm{Cl}$ & \\
\hline \multicolumn{6}{|l|}{ Energy (kJ) } \\
\hline Baseline & $4878 \cdot 65$ & 1.52 & $5214 \cdot 35$ & 1.55 & \\
\hline Near term & $5203 \cdot 55$ & $1 \cdot 44$ & $5552 \cdot 65$ & $1 \cdot 42$ & \\
\hline Change & 0.94 & $0 \cdot 86,1 \cdot 03$ & 0.94 & $0 \cdot 86,1 \cdot 02$ & 0.685 \\
\hline \multicolumn{6}{|l|}{ Protein (g) } \\
\hline Baseline & $33 \cdot 27$ & $1 \cdot 73$ & $36 \cdot 56$ & $1 \cdot 67$ & \\
\hline Near term & $40 \cdot 11$ & $1 \cdot 56$ & $40 \cdot 65$ & $1 \cdot 49$ & \\
\hline Change & 0.83 & $0.74,0.93^{\star \star}$ & 0.90 & $0.82,0.99^{*}$ & $0 \cdot 305$ \\
\hline \multicolumn{6}{|l|}{ Fat $(\mathrm{g})$} \\
\hline Baseline & $30 \cdot 56$ & $2 \cdot 23$ & $31 \cdot 69$ & $2 \cdot 34$ & \\
\hline Near term & $33 \cdot 70$ & $1 \cdot 74$ & $34 \cdot 04$ & $1 \cdot 82$ & \\
\hline Change & 0.91 & $0.78,1.06$ & 0.93 & $0 \cdot 80,1 \cdot 09$ & 0.827 \\
\hline \multicolumn{6}{|c|}{ Carbohydrates (g) } \\
\hline Baseline & $181 \cdot 30$ & $1 \cdot 45$ & $191 \cdot 87$ & $1 \cdot 54$ & \\
\hline Near term & $189 \cdot 54$ & $1 \cdot 46$ & $206 \cdot 02$ & $1 \cdot 45$ & \\
\hline Change & 0.96 & $0 \cdot 87,1 \cdot 05$ & 0.93 & $0 \cdot 85,1 \cdot 02$ & 0.395 \\
\hline \multicolumn{6}{|l|}{$\mathrm{Fe}(\mathrm{mg})$} \\
\hline Baseline & $6 \cdot 82$ & $2 \cdot 02$ & $7 \cdot 65$ & $1 \cdot 88$ & \\
\hline Near term & $8 \cdot 51$ & $1 \cdot 86$ & $7 \cdot 78$ & $1 \cdot 73$ & \\
\hline Change & $0 \cdot 80$ & $0 \cdot 68,0.94^{\star *}$ & 0.98 & $0 \cdot 85,1 \cdot 14$ & 0.414 \\
\hline Vitamin C (mg) & \multicolumn{2}{|c|}{ (n 107) } & & & \\
\hline Baseline & $50 \cdot 30$ & $3 \cdot 40$ & $47 \cdot 68$ & $2 \cdot 91$ & \\
\hline Near term & $40 \cdot 67$ & $2 \cdot 39$ & $54 \cdot 78$ & $2 \cdot 47$ & \\
\hline Change & $1 \cdot 24$ & $0.96,1.59$ & 0.87 & $0 \cdot 69,1 \cdot 11$ & 0.024 \\
\hline
\end{tabular}

Supplementary foods excluded.

${ }^{\star} P<0.05,{ }^{\star \star} P<0.01$ for significant change from baseline (paired $t$ test).

tAdjusted for baseline factors: altitude, gestational week, maternal height and supplement intake; and energy, protein, fat, carbohydrates, Fe and vitamin C intakes (analysis of covariance).

more $\mathrm{Fe}$ in women who received the supplementary food. In comparison with the additional Fe intake from the supplementary food $(24.6 \mathrm{~kg}$ over the whole study period, with an average Fe content of $1.755 \mathrm{mg} / 100 \mathrm{~g}$ ), this represents an absorption of only $5 \cdot 1 \%$ of the $\mathrm{Fe}$ in the supplementary food provided. The lack of effect in our study may have been caused by the factors given below. 
Table 7 Birth outcomes

\begin{tabular}{|c|c|c|c|c|c|c|c|}
\hline & \multicolumn{2}{|c|}{ Optimized diet ( $n$ 121) } & \multicolumn{2}{|c|}{ Control ( $n$ 118) } & \multicolumn{2}{|c|}{ Differencet } & \multirow[b]{2}{*}{$P$} \\
\hline & Mean & SD & Mean & SD & Mean & $95 \% \mathrm{Cl}$ & \\
\hline Feeding days until delivery & $135 \cdot 86$ & $21 \cdot 01$ & - & - & & & \\
\hline Total supplementary food given $(\mathrm{g})$ & $32957 \cdot 64$ & $5040 \cdot 18$ & - & - & & & \\
\hline Tempeh (g) & $13367 \cdot 71$ & $2061 \cdot 59$ & - & - & & & \\
\hline Animal-source food (g) & $1804 \cdot 79$ & $317 \cdot 87$ & - & - & & & \\
\hline Vitamin C-rich fruit (g) & $17785 \cdot 14$ & $2799 \cdot 62$ & - & - & & & \\
\hline Total supplementary food consumed $(\mathrm{g})$ & $30703 \cdot 81$ & $5493 \cdot 23$ & _- & - & & & \\
\hline Tempeh $(\mathrm{g})$ & $12010 \cdot 92$ & $2657 \cdot 19$ & - & - & & & \\
\hline Animal-source food (g) & $1684 \cdot 83$ & $362 \cdot 98$ & - & - & & & \\
\hline Vitamin C-rich fruit (g) & $17008 \cdot 06$ & $2820 \cdot 37$ & - & - & & & \\
\hline Measurement taken $(\mathrm{d}) \ddagger$ & $1 \cdot 0$ & $1 \cdot 0-2 \cdot 0$ & $1 \cdot 0$ & $1 \cdot 0-2 \cdot 25$ & & & 0.036 \\
\hline Gestation at birth (weeks) $\ddagger$ & 40 & $38-40$ & 39 & $38-40(n 119)$ & & & 0.370 \\
\hline Birth weight (g) & 3014 & 457 & 3102 & 405 & 37 & $-74,148$ & 0.512 \\
\hline Birth length $(\mathrm{cm})$ & $48 \cdot 37$ & $2 \cdot 0$ & $48 \cdot 84$ & $1 \cdot 89$ & $0 \cdot 22$ & $-0.27,0.72$ & 0.372 \\
\hline Low birth weight $(n, \%)$ & 18 & $14 \cdot 9$ & 9 & $7 \cdot 6$ & & & $0.077 \|$ \\
\hline Preterm birth $(n, \%)$ & 14 & $11 \cdot 6$ & 12 & $10 \cdot 1(n 119)$ & & & $0.481 \|$ \\
\hline Infant's sex (boy/girl; $n$ ) & $64 / 57$ & & $61 / 58$ & & & & $0 \cdot 800 \|$ \\
\hline Early neonatal mortality $(n)$ & 0 & & 2 & & & & \\
\hline Maternal BMI $\left(\mathrm{kg} / \mathrm{m}^{2}\right)$ & $23 \cdot 11$ & $3 \cdot 25$ & $22 \cdot 89$ & $2 \cdot 92$ & $-0 \cdot 11$ & $-0.92,0.71$ & 0.799 \\
\hline$<18.5(n, \%)$ & 4 & $3 \cdot 3$ & 7 & $5 \cdot 9$ & & & $0.333 \|$ \\
\hline \multicolumn{8}{|l|}{ Maternal weight (kg) } \\
\hline Baseline§ & $48 \cdot 33$ & $1 \cdot 18(n 127)$ & $49 \cdot 69$ & $1 \cdot 15(n$ 125) & & & 0.866 \\
\hline Near term§ & $56 \cdot 21$ & $1 \cdot 16(n 107)$ & $56 \cdot 45$ & $1 \cdot 13(n 116)$ & & & \\
\hline Postpartum§ & $52 \cdot 00$ & $1 \cdot 17$ & $52 \cdot 83$ & $1 \cdot 14$ & & & \\
\hline
\end{tabular}

Mean and SD unless otherwise indicated.

tMean and $95 \% \mathrm{Cl}$ adjusted for altitude, gestational week, maternal height, supplements intake; $P$ values were calculated using the $t$ test.

$\ddagger$ Median and interquartile range; $P$ values were calculated using the Mann-Whitney $U$ test.

SGeometric mean and SD; $P$ values were calculated using repeated-measures ANOVA.

॥Calculated using logistic regression analysis (Forward Wald method), controlled for altitude, gestational week, maternal height and supplement intake. 
First, the relatively good Fe status and the lower than expected prevalence of ID in our study population might not have been severe enough to detect an effect and may have biased our results. It is well known that Fe absorption becomes more effective as Fe stores become depleted $^{(22)}$. In our study, treatment effects were most pronounced in women who had ID at baseline. In these women, the effect of our supplementary food on plasma ferritin concentration was greater than the effect in the control group or in Fe-replete women. Three times larger reductions were seen in Fe-replete women compared with Fe-deficient women with regard to plasma ferritin concentration and body Fe stores.

Second, the amount of Fe in our study was low and the duration of our study may have been inadequate to observe the effects on Fe status as our primary outcome. In comparison with the standard supplementation programme for pregnant women in Indonesia with an additional intake of $5400 \mathrm{mg}$ of $\mathrm{Fe}(60 \mathrm{mg}$ of $\mathrm{Fe}$ for $90 \mathrm{~d}$ ), the additional amount of $\mathrm{Fe}$ in the supplementary food (on average $433 \mathrm{mg}$ over the whole study period) was only approximately $8 \%$; in general, Fe from food is less bioavailable compared with that from chemical preparations.

Third, the women in the present study had relatively good energy and protein intakes, and their habitual diet contained $1.434 \mathrm{mg}$ of $\mathrm{Fe} / 1000 \mathrm{~kJ}$ with a relatively high amount of vitamin C $(9.799 \mathrm{mg} / 1000 \mathrm{~kJ})$. Therefore, the additional vitamin $\mathrm{C}$ and other nutrients in our supplementary food might not have been as active as in other kinds of diets. For example, in one study even large amounts of ascorbic acid had only a modest effect on Fe absorption from soya ${ }^{(23)}$.

Fourth, we did not find a high prevalence of intestinal parasites, which could have increased the requirement for Fe. In the present study, $23.8 \%$ of pregnant women had light infestation with hookworms and $6.7 \%$ had trichuriasis; further, at baseline we could see only a weak effect of trichuriasis but not of hookworm on $\mathrm{Hb}$ concentrations.

In addition, we found no evidence that supplementary food had an effect on inflammation status and birth outcomes. The prevalence of inflammation was low and mild. The mean birth weight (3057 g) was comparable to that reported in a previous study on another island of Indonesia ${ }^{(24)}$; however, birth weight in our population was much higher than that in a study in Nepal (2733 g), in which an effect on birth weight could be seen with a daily antenatal multiple micronutrient supplement ${ }^{(25)}$.

In conclusion, increasing $\mathrm{Fe}$ and ascorbic acid from tempeh and vitamin C-rich fruits did not improve the Fe status of pregnant women in rural Indonesia with a relatively good traditional diet. It is possible, however, that our optimized diet could produce a detectable increase in Fe stores in some other target groups and in other situations, as shown in our subgroup analyses for pregnant women with ID.

\section{Acknowledgements}

The present research was supported by the Nestlé Foundation (Switzerland) for the Study of Problems of Nutrition in the World. The authors have no conflict of interest to declare. M.W.-E. and S.M. contributed to the supervision of data collection; J.G.E. contributed to blood sample analyses; M.W.-E. contributed to data analyses and to manuscript preparation. All authors contributed to the study design, to data interpretation and to critical revision of the manuscript. The authors thank the pregnant women, their infants and their families for their involvement in the trial. They also thank the field team members (Widya Rahmawati, Yuridayati, Keszia Tuni Sulistyo Utami, Ani Noviani and Wawin Misterianingtyas); the local field staff; the staff of the District Health Department of Karanganyar and Demak; the laboratory staff of the Parasitology Sebelas Maret University, Solo, and of the Diponegoro University, Semarang, staff of the Karanganyar District General Hospital, and of the Clinic Patology Diponegoro University, Semarang; and the health staff of Puskesmas Ngargoyoso, Puskesmas Jenawi, Puskesmas Tawangmangu, Puskesmas Bonang 1, Puskesmas Karangawen 2 and Puskesmas Demak 2, for their support.

\section{References}

1. UN System Standing Committee on Nutrition (2004) The 5th Report on the World Nutrition Situation. Nutrition for Improved Development Outcomes. Geneva: WHO.

2. Food and Agriculture Organization of the United Nations/ World Health Organization (2002) Human Vitamin and Mineral Requirements. Report of a FAO/WHO Expert Consultation. Rome: FAO/WHO.

3. Neumann CG, Bwibo NO, Murphy SP et al. (2003) Animal source foods improve dietary quality, micronutrient status, growth and cognitive function in Kenyan school children: background, study design and baseline findings. J Nutr 133, Suppl. 11, S3941-S3949.

4. Gibson RS \& Hotz C (2001) Dietary diversification/ modification strategies to enhance micronutrient content and bioavailability of diets in developing countries. $\mathrm{Br} J$ Nutr 85, Suppl. 2, S159-S166.

5. Erhardt J (2007) Nutrition surveys and calculations: guidelines, software and additional information. http://www. nutrisurvey.de (accessed November 2007).

6. Hurrell RF, Reddy MB, Juillerat MA et al. (2003) Degradation of phytic acid in cereal porridges improves iron absorption by human subjects. Am J Clin Nutr 77, 1213-1219.

7. McFarlane BJ, van der Riet WB, Bothwell TH et al. (1990) Effect of traditional oriental soy products on iron absorption. Am J Clin Nutr 51, 873-880.

8. Kasaoka S, Astuti M, Uehara M et al. (1997) Effect of Indonesian fermented soybean tempeh on iron bioavailability and lipid peroxidation in anaemic rats. J Agric Food Chem 45, 195-198.

9. Sutardi \& Buckle KA (1985) Reduction in phytic acid levels in soybeans during tempeh production, storage and frying. J Food Sci 50, 260-263.

10. Takashima-Sasaki K, Komiyama M, Adachi T et al. (2006) Effect of exposure to high isoflavone-containing diets on prenatal and postnatal offspring mice. Biosci Biotechnol Biochem 70, 2874-2882. 
11. Tempeh Info (2008) Tempeh FAQ. http://www.tempeh. info/faq/faq.php (accessed December 2008).

12. Hartini TNS, Winkvist A, Lindholm L et al. (2003) Food patterns during an economic crisis among pregnant women in Purworejo district, Central Java, Indonesia. Food Nutr Bull 24, 256-267.

13. Asobayire FS, Adou P, Davidsson L et al. (2001) Prevalence of iron deficiency with and without concurrent anemia in population groups with high prevalences of malaria and other infections: a study in Côte d'Ivoire. Am J Clin Nutr 74, 776-782.

14. Sauberlich HE (1999) Iron. In Laboratory Tests for the Assessment of Nutritional Status, 2nd ed., pp. 343-369 [I Wolinsky, editor]. Boca Raton, FL: CRC Press.

15. Thurnham DI (2008) Handling data when inflammation is detected. SIGHT AND LIFE Magazine 2, 49-52.

16. Erhardt JG, Estes JE, Pfeiffer CM et al. (2004) Combined measurement of ferritin, soluble transferrin receptor, retinol binding protein, and C-reactive protein by an inexpensive, sensitive, and simple sandwich enzyme-linked immunosorbent assay technique. J Nutr 134, 3127-3132.

17. World Health Organization/Centers for Disease Control and Prevention (2005) Assessing the Iron Status of the Population. Report of a Joint World Health Organization/ Centers for Disease Control and Prevention Technical Consultation on the Assessment of Iron Status at the Population Level. Geneva: WHO.

18. World Health Organization (1991) Basic Laboratory Methods in Medical Parasitology. Geneva: WHO.
19. Oqueka T, Supali T, Ismid IS et al. (2005) Impact of two rounds of mass drug administration using diethylcarbamazine combined with albendazole on the prevalence of Brugia timori and of intestinal helminthes on Alor Island, Indonesia. Filaria J 4, 1-13.

20. Cook JD, Flowers CH \& Skikne BS (2003) The quantitative assessment of body iron. Blood 101, 3359-3364.

21. Beaton GH (2000) Iron needs during pregnancy: do we need to rethink our targets? Am J Clin Nutr 72, Suppl. 1S, S265-S271.

22. Andang'o PE, Osendarp SJ, Ayah R et al. (2007) Efficacy of iron-fortified whole maize flour on iron status of schoolchildren in Kenya: a randomised controlled trial. Lancet 369, 1799-1806.

23. Gillooly M, Torrance JD, Bothwell TH et al. (1984) The relative effect of ascorbic acid on iron absorption from soy-based and milk-based infant formulas. Am J Clin Nutr 40, 522-527.

24. Shankar AH, Jahari AB, Sebayang SK et al. (2008) Supplementation with Multiple Micronutrients Intervention Trial (SUMMIT) Study Group. Effect of maternal multiple micronutrient supplementation on fetal loss and infant death in Indonesia: a double-blind cluster-randomised trial. Lancet 371, 215-227.

25. Osrin D, Vaidya A, Shrestha Y et al. (2005) Effects of antenatal multiple micronutrient supplementation on birthweight and gestational duration in Nepal: double-blind, randomised controlled trial. Lancet 365, 955-962. 